\title{
Productivity of cassava and other crops in an intercropping system
}

\author{
Daniel V. Silva', Evander A. Ferreira², Maxwel C. Oliveira ${ }^{2}$, Gustavo A. \\ M. Pereira ${ }^{3}$, Renan R. Braga ${ }^{3}$, José B. dos Santos², Ignácio Aspiazu ${ }^{4}$, and \\ Matheus F. Souza ${ }^{2}$ \\ ${ }^{1}$ Federal University Rural of Semi-Árido, Mossoró, Postal Code - 59.625-900, Rio Grande do Norte, Brazil. \\ ${ }^{2}$ Federal University of Vales of Jequitinhonha and Mucuri. Diamantina, Postal Code - 39.100-000, Minas \\ Gerais, Brazil. \\ ${ }^{3}$ Federal University of Viçosa. Viçosa, Postal Code - 36.570-000, Minas Gerais, Brazil. \\ ${ }^{4}$ State University of Montes Claros. Janaúba, Postal Code - 39440000, Minas Gerais, Brazil.
}

\begin{abstract}
D.V. Silva, E.A. Ferreira, M.C. Oliveira, G.A.M. Pereira, R.R. Braga, J.B. dos Santos, I. Aspiazu, and M.F. Souza. 2016. Productivity of cassava and other crops in an intercropping system. Cien. Inv. Agr. 34(1):159-166. Intercropping is a common practice among farmers in tropical regions of the world and has persisted for years, not only for traditional reasons, but also for certain advantages that helped in its ecological adaptation. In regard to low income farmers with small areas for cultivation, more attention should be given to the cost of production and better land management. Thus, the aim of this work was to determine the best intercropping system of cassava with other crops. The experiment was conducted in an area belonging to the cassava (Manihot esculenta) producers of the Planalto de Minas district in Diamantina, Minas Gerais State, Brazil. The treatments comprised cassava intercropped with maize, beans and dwarf pigeon pea, as well as controls with and without weeding. The dry mass of shoots for maize, beans and dwarf-pigeon pea was affected by the presence of cassava. The productivity of cassava was dependent on cultivar and the intercropped crop. The highest harvest indexes were observed when cassava was intercropped with maize. In a general way, intercropping with maize and beans showed the highest area equivalence indexes and are recommended for the cassava crop.
\end{abstract}

Key words: Area equivalence index, harvest index, Manihot esculenta, policultivation systems.

\section{Introduction}

Cassava (Manihot esculenta Crantz) has, among the energetic crops, the easiest production for household consumption because of its low demands for manpower and its production, even

Received August 5, 2015. Accepted February 4, 2016. Correspondind author: freitasouza@yahoo.com.br in low fertility soils. It constitutes the main starchy ingredient in the human diet in the regions where it is cultivated, and it is consumed especially as flour, which is also a practical storage form (Patil et al., 2015; Onubuogu et al., 2014; Ferraro et al., 2015). Despite showing high productive potential, reaching over $100 \mathrm{tha}^{-1}$ in some studies, national productivity is low $(14 \mathrm{t}$ ha $\left.^{-1}\right)$ (IBGE, 2014). 
High yields with low production costs have been one of the goals of agricultural research. However, in regard to low income farmers with small areas for cultivation, production costs and better land management should receive more attention. In this context, intercropping can become a practice of great importance for subsistence agriculture (Gao et al., 2010; Iftekhar et al., 2006). According to de Oliveira (1993), in the face of edaphoclimatic adversities, the adoption of intercropping assures the farmer a more lucrative crop with lower risks.

For cassava, family farmers practice varied farming systems, usually without defined technical criteria and with low productivity. Using the best available resources, farmers employ large numbers of local cultivars with variable productivity, predominantly in areas in which soils have low assimilable phosphorus (Lorenzi, 2003).

Considering these aspects, research has frequently used an index that evaluates the efficiency of intercropping systems, based on the cultivated area. This index, called the "equivalent area index" (AEI), represents the area of land in monoculture crops that is necessary to provide the productivity equivalent to that obtained with intercropping (Choudhary et al., 2014; Távora et al., 1989).

Among the advantages of the intercropping system is the increase in productivity per area unit (Mattos et al., 2005). Rao and Morgado (1985) reported increases ranging from $60 \%$ to $90 \%$ in the productivity of cassava fields when intercropped with different crops. However, there are few studies that aim to compare different cultivars in this system.

Given the above information, the aim of this study was to determine the effects of various intercropping systems of cassava with other species on grain yield and land use efficiency.

\section{Material and methods}

The experiment was installed in November 2010 in an area belonging to cassava producers in the district of Planalto de Minas at Diamantina-MG, Brazil. The soil was characterized as a dystrophic Red Latosol, and its chemical analysis showed the following characteristics: a $\mathrm{pH}$ in water of 5.8; 6.5, 7.10 and $3.5 \mathrm{cmol}_{\mathrm{c}} \mathrm{dm}^{-3}$ of $\mathrm{H}+\mathrm{Al}$ (exchangeable acidity), $\mathrm{Ca}$ and $\mathrm{Mg}$, respectively; $1.1 \mathrm{mg} \mathrm{dm}^{-3}$ of $\mathrm{P}$; $104 \mathrm{mg} \mathrm{dm}^{-3}$ of $\mathrm{K}$; organic matter of $3.1 \mathrm{dag} \mathrm{kg}^{-1}$; and particle sizes of 37, 32 and $31 \mathrm{dag} \mathrm{kg}^{-1}$ of sand, silt and clay, respectively. Tillage was held with one row plowed and one row harrowed. A 4-14-8 (N$\mathrm{P}_{2} \mathrm{O}_{5}-\mathrm{K}_{2} \mathrm{O}$ ) fertilizer at a dose of $570 \mathrm{~kg} \mathrm{ha}^{-1}$ was used for the cassava and, 30 days after planting the other crops, a top-dressing was applied on the maize and beans at a dose of $100 \mathrm{~kg} \mathrm{ha}^{-1} \mathrm{of} \mathrm{N}$. The maximum and minimum temperatures and average monthly rainfall of the experimental area appear in Figure 1.

Cassava cultivation was made in a double row system at spacing of $0.5 \times 0.5 \times 2 \mathrm{~m}$, and a density of two stem cuttings $\mathrm{m}^{-1}$. It was opted to sow two maize rows, cultivar AL-25, with a $0.8 \mathrm{~m}$ spacing between rows ( $0.6 \mathrm{~m}$ from cassava) and 16 plants $\mathrm{m}^{-1}$. For the 'Carioquinha' common bean, three rows with a $0.5 \mathrm{~m}$ spacing and 15 plants $\mathrm{m}^{-1}$ were grown. Dwarf-pigeon pea, used as green mulch, was sown in three rows with a $0.5 \mathrm{~m}$ distance between them and at a density of ten plants $\mathrm{m}^{-1}$.

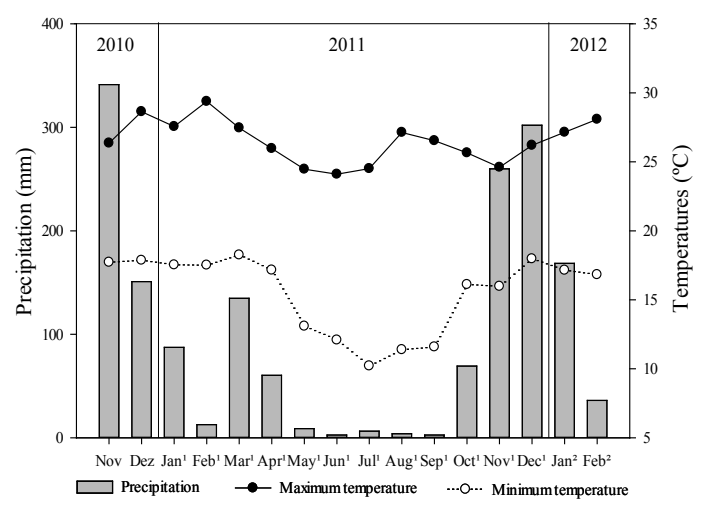

Figure 1. Precipitation and monthly averages of maximum and minimum temperatures. Planalto de Minas District, Diamantina, MG, Brazil, UFVJM, 2010 and 2011. 
The experiment was installed in a randomized blocks design (RBD), $2 \times 5$ factorial, with four replications. Factor A included cassava cultivars used in intercropping (Cacau-UFV and IAC-12), and factor $\mathrm{B}$ included crops intercropped with cassava, which were green mulch, dwarf-pigeon pea (Cajanus cajan), maize (Zea mays) [DKB 390 YGhybrid] and beans (Phaseolus vulgaris) ['Eldorado IPR'] as well as monocropped cassava, with and without weed control. The cassava productivity (PROD), shoots dry matter mass (SDMM) percentage, harvest index (HI) and equivalent area index (AEI) were evaluated.

At 60 days after crop emergence, the maize, beans and green mulch (dwarf-pigeon pea) plants were collected by sampling ten plants per plot, which were then packed into paper bags. The samples were transported to the laboratory and placed in a forced air circulation oven at $52{ }^{\circ} \mathrm{C}$ until a constant weight was obtained and then weighed on a precision scale to obtain the SDMM. The percentage of dry mass compared with the control (\% SDMM) was also calculated (crop grown in monocrop system).

The harvest of beans, maize and cassava was performed at 90, 150 and 460 days after emergence (DAE), respectively. For the harvest, 20 maize and beans plants were collected in each plot, and the grains were transported to the laboratory, dried to approximately $12 \%$ moisture and weighed. The cassava roots were weighed at the harvest site and, from that stage, the productivity was calculated for each evaluated crop.
The harvest index (HI) and the equivalent area index (AEI) were also calculated, according to the following equations:

$$
\mathrm{HI}(\%)=(\mathrm{GY} / \mathrm{BY}) * 100
$$

in which $\mathrm{HI}$ is the harvest index, GY is the commercial yield, and BY is the biological yield, and

$\mathrm{AEI}=\mathrm{Ac} / \mathrm{Am}+\mathrm{Bc} / \mathrm{Bm}$

in which $\mathrm{AEI}$ is the equivalent area index, Ac is the A crop intercropped, Am is the A crop monocropped, $\mathrm{Bc}$ is the $\mathrm{B}$ crop intercropped and $\mathrm{Bm}$ is the $\mathrm{B}$ crop monocropped.

The data were subjected to an analysis of variance and the means, when significant, were compared by Tukey's test at the $5 \%$ significance level.

\section{Results and discussion}

The shoot dry matter mass (SDMM) of maize and beans was not affected by intercropping with two cassava cultivars (Table 1). However, for dwarf-pigeon pea, intercropping with the IAC-12 reduced the accumulation of SDMM. According to Silva et al. (2012), the architecture and growth habit of cassava is directly related to the ability to tolerate the competition imposed by other plants in the initial phase. 'IAC-12' is a cultivar adapted to the region where the study was conducted and shows higher initial growth and interference with the development of dwarf pigeon pea.

Table 1. Mass of dry matter from shoots of maize, bean, and dwarf pigeon pea intercropping with two cassava cultivars.

\begin{tabular}{lccc}
\hline & Maize & Beans & Pigeon pea \\
\cline { 2 - 4 } Treatment & & g plant $^{-1}$ & \\
\hline Control & $33.54 \mathrm{~A}^{1}$ & $15.20 \mathrm{~A}$ & $22.00 \mathrm{~A}$ \\
IAC-12 & $33.83 \mathrm{~A}$ & $14.05 \mathrm{~A}$ & $9.75 \mathrm{~B}$ \\
Cacau-UFV & $32.38 \mathrm{~A}$ & $13.32 \mathrm{~A}$ & $19.25 \mathrm{~A}$ \\
CV $(\%)$ & 24.25 & 33.59 & 31.75 \\
\hline
\end{tabular}

${ }^{1}$ The means followed by the same uppercase letter in the column do not differ by the Tukey test at the $5 \%$ significance level. $\mathrm{CV}$ : Coefficient of variation corresponding to all data. 
In this work, the average cassava productivity was approximately $30 \mathrm{t} \mathrm{ha}^{-1}$. This productivity level is similar to that achieved in cassava fields in Pacajus, Ceará State (Tavora and Melo, 1993) and Cruz das Almas, Bahia State, (de Albuquerque et al., 2012); both of these areas are located in Brazil and have lower productivities than those obtained in the fields in Marechal Cândido Rondon, Paraná State, Brazil (Gabriel Filho et al., 2003).

It was verified that maize grown in a monocrop system showed greater PROD when compared with the other treatments (Table 2). Between the two cassava cultivars, greater PROD was observed when maize was grown with the 'IAC-12', without, however, differing significantly from Cacau-UFV (Table 2).

Regarding the beans, it was also observed that the control (monocropped beans) showed greater PROD in comparison with the other treatments, and in this case, the plots cultivated with Cacau-UFV were more productive compared with the beans and IAC-12 intercropping, without significant differences between them (Table 2).

The dry matter production between the intercropping systems and monoculture were not significantly different. However, it is evident that in evaluating the PROD, there was some level of competition between cultures when they were grown in an intercropping system.
When in competition, plants tend to relocate their photoassimilates to achieve greater competitiveness. Leaves and fine roots are important structures that can increase the competitive ability of species, allowing better access to growth resources (Silva et al., 2010). Thus, plants can relocate photoassimilates to these structures to increase their competitive advantage. This may have affected the productivity of maize and beans because a smaller amount of photoassimilates were available to the reproductive organs, resulting in lower production and/or grain filling.

When assessing the (PROD) of cassava intercropped with beans, maize and dwarf-pigeon pea (green mulch), the cultivar Cacau-UFV showed greater productivity when grown in a monocrop system with weeding (weeded control), differing from the treatments in which this cultivar was grown intercropped with maize, beans and green mulch (Table 3). Pypers et al. (2011) stated that intercropping cassava with legumes promotes soil fertility, but species with high biomass production and high length of competition reduce crop productivity. Rao and Mathuva (2000) achieved a 24\% increase in maize productivity with intercropped maize and pigeon pea compared with continuous maize monocropping. However, in the maize rotated with pigeon pea, the production was equivalent to continuous maize monocropping. Schons et al. (2009) found that the interspecific competition between the cassava and maize crops in intercropped systems at the spacings used in this study does not affect the growth and development

Table 2. Productivity of maize and bean intercropped with cassava (cultivars: Cacau-UFV and IAC-12).

\begin{tabular}{lcc}
\hline & Maize & Bean \\
\cline { 2 - 3 } Treatment & & $\mathrm{kg} \mathrm{ha}^{-1}$ \\
\hline Control & $3194.17 \mathrm{~A}^{1}$ & $780.83 \mathrm{~A}$ \\
Cacau - UFV & $1758.67 \mathrm{~B}$ & $488.75 \mathrm{~B}$ \\
IAC-12 & $1905.83 \mathrm{~B}$ & $459.10 \mathrm{~B}$ \\
CV (\%) & 13.45 & 12.64 \\
\hline
\end{tabular}

${ }^{1}$ The means followed by the same uppercase letter in the column do not differ by the Tukey test at the $5 \%$ significance level. $\mathrm{CV}$ : Coefficient of variation corresponding to all data. 
parameters and the productivity of both species when compared with the monocrop.

The presence of weeds caused a substantial decrease in the PROD of the Cacau-UFV cultivar (Table 3). Yadollahi et al. (2014) compared intercropping and monocropping for their ability to compete with weeds and found that intercropping reduced weed infestation because the weed biomass indices were lower in these systems compared with monocropping because they had the capacity to cover the ground faster. According to the same authors, monocropped beans also propitiated high ground cover, but the system proved to be inefficient in competition with weeds. Thus, the authors concluded that intercropping could be complementary to other methods for more efficient and economical weed control. According to Ballaré and Casal (2000), in an area infested with weeds, the quantity and quality of the light incident on the ground can change and thus affect crop development.

For the 'IAC-12' cultivar, it was verified that treatments in which cassava was grown monocropped with weed control and intercropped with beans showed higher productivity, and the treatment in which the crop was grown without weed control had the lowest productivity (Table 3). Devide et al. (2009) observed that maize, cultivar Eldorado, cultivated in alternated rows of cassava, after the first weeding, did not interfere in the production of commercial roots. De Albuquerque et al. (2012), working with several arrangements of cassava intercropped with beans, observed that the cassava in a double-row system plus a row of beans yielded an equivalent level of production to monocropping, both in single rows and in double rows.

De Albuquerque et al. (2012) obtained yields of commercial roots of $27.56 \mathrm{t} \mathrm{ha}^{-1}$ using double sowing rows $(2.00 \times 0.60 \times 0.60 \mathrm{~m})$ intercropped with peanuts (Arachis hypogea), while the monocrop yielded $25.32 \mathrm{t} \mathrm{ha}^{-1}$ in the same spacing; using simple rows, however, intercropping reduced productivity $\left(16.84 \mathrm{t} \mathrm{ha}^{-1}\right)$ compared with the monocrop $\left(19.99 \mathrm{t} \mathrm{ha}^{-1}\right)$. In a intercropping system with soybeans (Glycine max) for grain harvest, cassava caused a decrease in productivity, which was attributed to the water stress that occurred during the initial development period of the crops by Mattos et al. (1994).

The harvest index (HI) characterizes the ratio between the harvested part of the plant (roots) and the biomass of the shoots of cassava and indicates that it was altered by intercropping, differing between cultivars and the adopted intercropping systems (Table 3). The HI represents the conversion efficiency of photoassimilates to economic yield. As the height of the plants decreases, with lower straw production, $\mathrm{HI}$ increases. In a general way, cultivars with a greater yield potential show

Table 3. Productivity (ton ha ${ }^{-1}$ ), harvest index (HI - \%) and area equivalent index (AEI) of cassava (cultivars: Cacau - UFV and IAC-12) intercropped with maize, bean, and pigeon pea.

\begin{tabular}{|c|c|c|c|c|c|c|}
\hline \multirow[b]{3}{*}{ Treatment } & \multicolumn{2}{|c|}{ PROD } & \multicolumn{2}{|c|}{$\mathrm{HI}$} & \multicolumn{2}{|c|}{ AEI } \\
\hline & Cacau & IAC-12 & Cacau & IAC-12 & Cacau & IAC-12 \\
\hline & \multicolumn{2}{|c|}{ ton $\mathrm{ha}^{-1}$} & \multicolumn{2}{|c|}{$\%$} & & \\
\hline Pigeon pea & $30.25 \mathrm{~B}^{1}$ & $32.05 \mathrm{~B}$ & $48.50 \mathrm{~B}$ & $49.90 \mathrm{~B}$ & - & - \\
\hline Weeding & $40.75 \mathrm{~A}$ & $42.25 \mathrm{~A}$ & $60.98 \mathrm{~B}$ & $61.14 \mathrm{AB}$ & - & - \\
\hline Bean & $31.75 \mathrm{~B}$ & $42.75 \mathrm{~A}$ & $55.00 \mathrm{~B}$ & $50.00 \mathrm{~B}$ & $1.40 \mathrm{~A}$ & $1.60 \mathrm{~A}$ \\
\hline Maize & $26.85 \mathrm{~B}$ & $26.70 \mathrm{~B}$ & $86.65 \mathrm{~A}$ & $71.41 \mathrm{~A}$ & $1.61 \mathrm{~A}$ & $1.29 \mathrm{~B}$ \\
\hline Weed & $7.25 \mathrm{C}$ & $11.50 \mathrm{C}$ & $50.57 \mathrm{~B}$ & $38.92 \mathrm{C}$ & - & - \\
\hline CV (\%) & \multicolumn{2}{|c|}{15.53} & \multicolumn{2}{|c|}{22.18} & \multicolumn{2}{|c|}{18.12} \\
\hline
\end{tabular}

${ }^{1}$ The means followed by the same uppercase letter in the row do not differ by the Tukey test at the $5 \%$ significance level. $\mathrm{CV}$ : Coefficient of variation corresponding to all data. 
a high HI. However, it is not true that all the cultivars with a high HI show high yield potentials (Floss, 2004).

A higher HI was observed when the 'Cacau-UFV' was intercropped with maize, which differed from the other treatments. In this case, a lower HI value was observed for intercropping of 'Cacau-UFV' with dwarf pigeon pea. For 'IAC-12', a lower HI was observed for the treatment in which this cultivar grew without weeding, and a higher HI was observed when cassava was intercropped with maize, although it did not differ from the weeded control (Table 3). Devide et al. (2009) analyzed intercropping systems of cassava with maize and cowpea and did not observe differences in the harvest index between treatments.

For the area equivalence index (AEI), an advantage was found for all the evaluated intercropping systems (Table 3). This index quantifies the number of hectares necessary for reductions in monocrops to be equal to one hectare of the same crops when intercropped. The behavior of intercropped crops is different from that observed for monocrops. The same differences occur to the interference relationships of intercrops or monocrops with weeds, which are also modified (Severino and Christoffoleti, 2001).

By evaluating the AEI for each cassava cultivar, it was verified that for 'Cacau-UFV', intercropping with maize provide the best results, and for 'IAC-12", the best results were found when intercropping with beans. Regarding the cultivars studied for each crop, it was observed that, for maize, 'Cacau-UFV' showed a higher AEI, and for beans, it was 'IAC-12' (Table 3).

Evaluating the land use efficiency and the yields of maize, beans and sunflower in intercropping systems in Guaíba-RS, Machado et al. (1984) report that the three types of intercropping used showed higher land use efficiency (LUE) values than corresponding monocrops. Intercropping beans and maize showed a LUE value of 1.18, which is a LUE that is approximately $18 \%$ higher than that of monocropped beans and maize. The advantages in relation to monocropping are due to the better utilization of the available resources, such as light, water and nutrients.

According to the results, it can be observed that the two evaluated cultivars showed different behaviors when intercropped with different crops. Both cultivars present higher productivity, as expected, when monocropped, and 'IAC-12' shows similar productivity to the weeded and monocropped control when intercropped with beans. 'Cacau-UFV', intercropped with maize, and 'IAC-12', intercropped with beans, show high area equivalence indexes; the latter shows values higher than 1.60 .

Cassava is characterized by slow initial growth and as a low soil cover crop. Thus, intercropping with other crops such as maize and beans has proven to be highly viable, as can be observed by the high HI values for cassava and AEI for the crops in this study. Another important fact is that cassava has an annual or biennial production cycle, which slows the recovery of the investment when compared with faster cycle crops such as beans and maize. In this way, intercropping with beans and maize becomes an important source of income for the farmer in periods when costs are elevated due to the needs of cassava.

The growth of maize, beans and dwarf pigeon pea is affected by the presence of cassava. Cassava productivity is dependent on the cultivar used and the intercropped crop.

In a general way, intercropping with maize and beans provides the best area equivalence indexes and is more recommended for cassava. 


\section{Acknowledgements}

The authors thank the State of Minas Gerais Research Foundation (FAPEMIG), the Coor- dination for Improvement of Higher Personnel (CAPES) and the National Council for Scientific and Technological Development (CNPq), Brazil, for the support and research grants.

\section{Resumen}

D.V. Silva, E.A. Ferreira, M.C. Oliveira, G.A.M. Pereira, R.R. Braga, J.B. dos Santos, I. Aspiazu y M.F. Souza. 2016. La productividad de los cultivos de yuca en un sistema de cultivo intercalado. Cien. Inv. Agr. 43(1):159-166. Intercalar cultivos es una práctica común entre los agricultores de las regiones tropicales del mundo, que ha persistido a lo largo de los años, no sólo por tradición, sino también por la búsqueda de las ventajas que han ayudado en su adaptación ecológica.Cuando se considera a agricultores con pequeñas propiedades de cultivo y bajos ingresos económicos, se debe poner más atención en los costos de producción y en el mejor aprovechamiento de la tierra. Así pues, el objetivo de este trabajo fue determinar el mejor sistema de intercalar la yuca con otros cultivos. El experimento se realizó en un área perteneciente a los productores de yuca (Manihot esculenta) del distrito de Planalto de Minas en Diamantina, Minas Gerais, Brasil. Los tratamientos consistieron en intercalar la yuca con maíz, frijoles y guisantes enano paloma, así como los controles con y sin deshierbe. La producción de materia seca de rebrote de maíz, frijoles y guisantes enano paloma se vio afectada por la presencia de yuca. La productividad de la yuca depende de la variedad utilizada y de los cultivos intercalados. Los mayores índices de cosecha se observaron cuando la yuca se intercaló con maíz. De forma general se puede afirmar que el cultivo de la yuca, intercalado con maíz y frijol, muestra los índices de equivalencia área más altos, siendo el más recomendado para el cultivo de la yuca.

Palabras clave: Índice de cosecha, índice equivalencia área, Manihot esculenta, sistemas de policultivo.

\section{References}

Ballaré, C.L., and J.J. Casal. 2000. Light signals perceived by crop and weed plants. Field Crops Research 67: 149-160.

BRASIL, I. B. G. E. Instituto Brasileiro de geografia e Estatística. Censo Demográfico 2000, 2008. Available online at: < ftp://ftp.ibge.gov. br/Producao_Agricola/Levantamento_Sistematico_da_Producao_Agricola_[mensal]/Comentarios/lspa_201401comentarios.pdf > (Website accessed

Choudhary, V., A. Dixit, and P.S. Kumar. 2014. Productivity, competition behaviour and weed dynamics of various row proportions of maize
(Zea mays)-legumes intercropping in Arunachal Pradesh. The Indian Journal of Agricultural Sciences $84 \mathrm{pp}$.

de Albuquerque, J.A.A., T. Sediyama, J.M.A. Alves, A.A. da Silva, and S.C.P. Uchôa. 2012. Cultivo de mandioca e feijão em sistemas consorciados realizado em Coimbra, Minas Gerais, Brasil. Revista Ciência Agronômica 43: 532-538.

de Oliveira, F.J. 1993. Combinações de espaçamentos e populações de plantas de caupi* e de milho em monocultura e consorciados. Pesquisa Agropecuária Brasileira 28: 931-945.

Devide, A.C.P., R.L.D. Ribeiro, T.L. Valle, D.L. Almeida, C.M. Castro, and J.C. Feltran. 2009. Produtividade de raízes de mandioca consor- 
ciada com milho e caupi em sistema orgânico. Bragantia 68: 145-153.

Floss, E.L. 2004. Fisiologia das plantas cultivadas: o estudo que está por trás do que se vê. Publisher UPF, Passo Fundo, Brazil, 536 pp.

Gabriel Filho, A., L. Strohhaecker, and E. Fey. 2003. Profundidade e espaçamento da mandioca no plantio direto na palha. Ciênc rural 33: 461-467.

Gao, Y., A. Duan, X. Qiu, Z. Liu, J. Sun, J. Zhang, and H. Wang. 2010. Distribution of roots and root length density in a maize/soybean strip intercropping system. Agricultural water management 98: 199-212.

Iftekhar, H., A. Riaz, J. Abdul, M. Nazir and T. Mahmood. 2006. Competitive behavior of component crops in different Sesame-Legume intercropping systems. Journal of agriculture and Biolology 2: 165-167.

Jansen van Rijssen, F. W., E. J. Morris, and J. N. Eloff. 2013. Food safety: importance of composition for assessing genetically modified cassava (Manihot esculenta Crantz). Journal of Agricultural and Food Chemistry 61: 8333-8339.

Lorenzi, J. 2003. Mandioca. Campinas: CATI. São Paulo, Boletim técnico 245. 110 pp.

Machado, C.M.N., N.G. Fleck, and R.S. de Souza. 1984. Eficiência na utilização da terra e rendimentos das culturas em consórcio. Pesquisa Agropecuária Brasileira 19: 317-327.

Mattos, P., A. Souza, and R. Caldas. 1994. Avaliação do cultivo da mandioca em fileiras duplas e simples consorciada com soja. Revista Brasileira de Mandioca 13:47-59.

Mattos, P., L.S. Souza, J.S. Souza, and R.C. Caldas. 2005. Consorciação da mandioca plantada em fileiras duplas e simples com culturas de ciclo curto. I. mandioca x caupi x milho. Revista Brasileira de Mandioca 18: 25-30.

Onubuogu, G., N. Esiobu, C. Nwosu, and C. Okereke. 2014. Resource use efficiency of smallholder cassava farmers in Owerri Agricultural zone, Imo State, Nigeria. Scholarly Journal of Agricultural Science Vol 7: 142-152.
Patil, B.L., J.P. Legg, E. Kanju, and C.M. Fauquet. 2015. Cassava brown streak disease: a threat to food security in Africa. Journal of General Virology 96: 956-968.

Pypers, P., J.M. Sanginga, B. Kasereka, M. Walangululu, and B. Vanlauwe. 2011. Increased productivity through integrated soil fertility management in cassava-legume intercropping systems in the highlands of Sud-Kivu, DR Congo. Field Crops Research 120: 76-85.

Rao, M., and M. Mathuva. 2000. Legumes for improving maize yields and income in semi-arid Kenya. Agriculture, ecosystems \& environment 78: 123-137.

Rao, M., and L. Morgado 1985. Consorciação com a cultura da mandioca no Nordeste do Brasil: Resultados atuais e perspectivas para futuras pesquisas. EMBRAPA-CPATSA. 22 pp. Documentos 32 .

Schons, A., N.A. Streck, L. Storck, G.A. Buriol, A.J. Zanon, D.G. Pinheiro, and B. Kraulich. 2009. Arranjos de plantas de mandioca e milho em cultivo solteiro e consorciado: crescimento, desenvolvimento e produtividade. Bragantia 68: 155-167.

Severino, F.J., and P.J. Christoffoleti. 2001. Banco de sementes de plantas daninhas em solo cultivado com adubos verdes. Bragantia 60: 201-204.

Silva, D., J. Santos, E. Ferreira, A. Silva, A. França, and T. Sediyama. 2012. Manejo de plantas daninhas na cultura da mandioca. Planta daninha 30: 901-910.

Távora, F., F. da Silva, F. Melo, and F. Costa Neto. 1989. Consórcio da mandioca com culturas leguminosas de ciclo curto. Revista Brasileira de Mandioca 8:37-46.

Tavora, F.J.A.F., and F.I.O. Melo. 1993. Crescimento e produção da mandioca submetida a dois arranjos de plantio. Pesquisa Agropecuária Brasileira 28: 823-832.

Yadollahi, P., A.R.B. Abad, M. Khaje, and M. Reza. 2014. Effect of intercropping on weed control in sustainable agriculture. International Journal of Agriculture and Crop Sciences 7: 683. 